\title{
DEVELOPMENT OF STRATEGIC INNOVATION MANAGEMENT COMPONENTS
}

\author{
Cholpassorn Sitthiwarongchai \\ Viroj Jadesadalug \\ Chirawan Kongklai \\ Silpakorn University, Thailand, Bangkok
}

The concept of strategic innovation management is the psychological and social process with regard to the entire development of an organization. It represents the capability to create and transform the business management concept, i.e. administration management, marketing and entire business system of an organization to enhance its sustainable competitive advantage. This research study of the strategic innovation management is based on the fundamental concepts and theories such as (1) the Resource-Based View (RBV) Theory, (2) Contingency Theory and (3) Dynamic Capability. It is found that the main variable factors shaping the concept of strategic innovation management consists of (1) networking business, (2) quick response to technology, (3) integrated management process, (4) flexible resource allocation and (5) creativity development beneficial when being applied for the development of the conceptual framework or organization development through various variables in order to set the future strategic innovation management for an organization.

Keywords: strategic innovation management, networking business, quick response to technology, integrated management process, flexible resource allocation, creativity development.
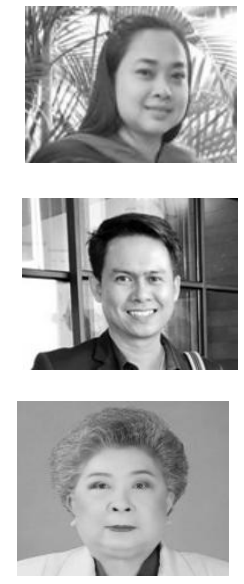

Cholpassorn Sitthiwarongchai

Faculty of Management Science Silpakorn University, Ph.D. student interests - Management, Marketing

E-mail: cholpassorn.si@gmail.com,yumiko_little@hotmail.com

Viroj Jadesadalug

Faculty of Management Science Silpakorn University, Asst. Prof. Dr. interests - Management, Business

E-mail: viroj@ms.su.ac.th,viroj_jade@hotmail.com

Chirawan Kongklai

Faculty of Management Science Silpakorn University, Assoc. Prof. Dr. interests - Management

E-mail: kongklai_c@su.ac.th 


\section{Introduction}

We are living currently in the era of changes in economic life, society, politics, technologies, and information technologies first of all, competitive business situation etc. In other words, it is the era of globalization or borderless world which affects all organizations in terms of their structure, strategy, corporate culture and management methods. Adhering to the originate business management methods which used to be successful and refusing to adapt to be in line with the current circumstances, any organization can hardly maintain its strength and long-term survival. This means all businesses and organizations have to adapt to be in accordance with the alterative context of business management in order to increase their competitive capabilities and guarantee own survival. Rapid changes in the global situation effect not only organizations but also consumers or customers who also are forced to adapt to these numerous changes. As a result of easier access to information, people can learn more rapidly today and increasingly access new and newer information resources. Therefore, their expectations and requirements in terms of quality of services and products are increasing as well. To respond to these newer customers' expectations, organizations have to try to increasingly create various new things, new concepts of innovation for both products and services including strategic development of management innovations. The latter enable them to be truly innovative organizations which are applying innovations as a tool to fight against severe business competition. Thus, only such organization are capable enough to adapt and change their business management to guarantee themselves both survival and sustainability.

The concept of strategic innovation management is the psychological and social process (Smale, 2016) explaining the capability of creating and transforming business and organizational concept by changes in marketing, management capability and organizational business system (Drejer, 2006) involving the entire organizational development. Although innovation in this context consists of various types of activities, the current research study on innovation was made using the results of the past studies on innovations divided into technology innovation, management innovation, future innovation as well as innovation increase that are the main factors enabling organizations to thrive sustainably (Blazevic et al., 2003; Jaspers et al., 2007; Oke, 2007). This is also in line with the 20-year National Strategy and National Economic Development 2015 which is focusing on creativity and innovation development as well as value added related to production process \& service models, technology change and business management model and in line with the Thailand 4.0 Policy. Transformation of economic structures to value-based economy forces various industries to place more importance on innovations since only innovation can create a competitive advantage for today's businesses (Tuna, 2015) and organizations of all types in both government and private sectors.

Considering the abovementioned, we can also state that strategic innovation management is significantly important for an organization in the process of applying its numerous factors of development. This research study focuses on the contribution of strategic innovation management based on the basic concepts and theories such as (1) the Resource-Based View (RBV) Theory, (2) Contingency Theory and (3) Dynamic Capability. Information from the related literature sources is also used for better understanding of the factors behind strategic innovation management. 


\section{DEVELOPMENT OF STRATEGIC INNOVATION}

\section{Objectives}

To determine the key factors for strategic innovation management on the basic concepts, empirical evidence as well as such theories as: (1) the Resource-Based View (RBV) Theory, (2) Contingency Theory and (3) Dynamic Capability Theory.

\section{Literatures Review}

The researchers have studied the following concepts and theories for further factor analysis and factors' determination in the context of strategic innovation management:

Resource-Based View (RBV) focuses on organization' $\mathrm{s}$ internal management capability, i.e., its internal resources and organization capability as the main principle for operating own competitive advantage and thus reaching certain results. It can be used for strategic planning which enables the organization to be capable and unique and this, in its own turn, enhances company's sustainable competitive advantage (Barney, 1991, 2001; Grant, 1991). RBV theory as such rests on 2 main factors; firstly, internal resources of an organization divided by Barney into 3 categories: (1) physical resources such as plant, equipment, machinery, location, technology, materials and assets etc.; (2) human resources such as employees, their capabilities, intelligence, teamwork, training and experience; (3) organizational resources such as organization structure, planning process, corporate culture, database, information system, trademark, copyright, patents, brand, image, popularity and recognizability etc. Secondly, ordinary capabilities which are skills, appropriate resources and also management capabilities (Kor \& Marhoney. 2004). The latter are responsible for smart resource utilization in accordance with an appropriate strategy to be beneficial to this particular organization (Wade \& Hulland, 2004), showing the satisfying result as expected and finally leading to business having its own competitive advantage (Dess \& Lumpkin, 2003).

The researchers in this particular article have used the RBV theory as the main principle to further explain the composition of strategic innovation management, referring to the resource-based factors, i.e, flexibility of resource allocation which can help organization have an appropriate strategy determination and thus be capable of implementing this strategy effectively and efficiently into real-life practice.

Contingency theory focuses on explanation of strategic management performed by executives in accordance with situation and environment that impacts the business operations (Otley,1980; Reje, 2004). Both these authors were stating that there can be no universality of ideally appropriate management system which can be equally applied to any organization and every situation. Efficiency of contingency theory management is subject to various factors and specific context arising in such organizations. In addition, efficiency will occur due to conformity of organization to both internal and external environment (Homburg et al., 2012). At the same time, different nature of business will lead to different environment and thus different methods of environmental management (Robbins \& Coulter, 2002) considered to be in line with uncertainty and instability of environment (Luthans \& Stewart, 1977). Contingency theory in our particular case serves as the basis for further explanation of the composition of strategic innovation management with the factors being in conformity with the contingency theory. 
Dynamic Capabilities concept focuses on integration of resources and capabilities existing in an organization to be in line with all related environmental changes. It is the strategic concept created under the resource-based view theory (Barney, 1991) emphasizing the unique resource integration must be in accordance with future opportunities (Teece, Pisano \& Shuen, 1997; Teece, 2012). This concept reflects that the environment is always instable and fluctuated. Consequently, development of new capabilities is always required to increase, while the actual volume of new resources must be in line with such fluctuations (Teece, Pisano \& Shuen, 1997). Dynamic capabilities do not focus on the interaction with the environment but on stepping over the environment that is there must be enough adaptability to step over any incoming change (Eisenhardt \& Martin, 2000; Teece, 2007). Dynamic capabilities can be explained in 2 aspects: (1) dynamic aspect which is an organization' $s$ capability to create a new thing to accommodate with the environmental change such as service, networking including creativity development etc. and (2) capability which means skills and new knowledge utilization for resource integration carried out regularly and continuously until having skills in each field of working and restructuring are in line with the incoming external change (Jantunen et al, 2012; Mckelvie \& Davidsson, 2009). Based on the scope of dynamic capabilities concept, the researchers use it as the basis to explain the conceptual framework of the dynamic capabilities concept for explaining the strategic innovation management having all factors in compliance with the dynamic capabilities concept that are business networking, business process integration and creativity development.

\section{Strategic Innovation Management}

Innovation means new things are being developed from knowledge, capability, skills, experience and creativity in a form of a product or a service to enhance economic benefits (Schilling, 2008; Utterback, 2004). This is in line with West and Farr' s concept (1990) stating that innovation is an applicable product process development concept or a new method of organization into groups or roles relevant to each department, inclusively contributing economic benefits towards personnel, various other groups of stakeholders, organization overall and also the whole society.

Strategic Innovation Management is the business working process management which is supposed to create more value added for customers as compared to competitors as well as to develop enough competitive capabilities for long-term accomplishment of various goals (Kijpokin Kasemsap, 2014; Bapkin, Lipatnikov. and Muraveva, 2015). Innovation management plays an important role in an organization since it helps supporting and enabling the organization in its utilizing of knowledge, skills, technologies and experience for new creation of products and services including methods of product manufacturing and product \& service delivery to customers. This is also in line with Bean and Radford (2002) and Lee Yuan-Duen and Huan Ming Chang (2008). The concept of innovation management has been already widely extended and today is not limited to only newer inventions in term of product innovation or new service model, but also includes the method of applying multi-purpose technology that will increasingly impact economy, society, culture as well as people's living. Nowadays, innovation management can really shape the competitive capabilities of organizations and it is also important for their survival, no matter which sector we are talking about, private or public. However, innovation management in each particular organization 


\section{DEVELOPMENT OF STRATEGIC INNOVATION}

would always vary due to different targets set and the present situation with innovation management. It requires, inter alia, taking into account the process of innovative creativity and also capability of an organization' s executives towards innovation management as such.

\section{Results}

After a thorough review of the related literature sources, concepts and fundamental theories, we have found that the factors directly involved in strategic innovation management include the following:

Business Networking which means communication, coordination with suppliers sponsors, alliances, business stakeholders and customers through sharing, exchanging of all related information with each other to stimulate better management and quality control for all organization' s operations (Modell, 1996; Moller \& Svahn, 2009; Munksgaard et al., 2012). Networking as such is nearly always positive for business relationship since it often results in its own expansion on both domestic and international markets thus causing a direct effect on customers' value perception including their expectations as to the creation of more opportunities to strengthen business organization (Hohenthal et al., 2014). In addition, as per this study, innovation management concept links the guideline setting with responding to customers' demand, establishment of networking organization, organizational sustainability, business flexibility, intellectual property creation, new business model development and global innovation management (Horn \& Brem, 2013). Interpersonal contact and cooperation are significant for innovation development since both are showing the significance of networking establishment in innovation management, cooperation between organizations in order to pave the way for further sharing, joint development of ideas and coworking having the associated technologies (Proctor, 2013).

Quick Response to Technology means an awareness of business organization as well as placing importance on transforming itself to cope with rapid technological changes. Information technology is an essential tool contributing to better efficiency and flexibility of an organization and it is also a significant factor in the process of competitive advantage creation. Rapid introduction of extensive technologies together with new products' roll-out in any new market shows that innovation is essential to any organization (Mathisen and Einarsen, 2004). And as it is stated by by Tony Proctor (2013) information technology involves with innovation development being in parallel to communication between personnel and organization in terms of information sharing which enhances innovation. This is in line with (Cooper, 1988) who stated quite a while ago that cointegration of technology and marketing under support on the side of top executives with the inclusive internal and external communication channels affect effective innovation management overall.

Today's worldwide business competition is the result of information technologies' influence, new quality of products and services, new production capabilities as well as transformation of capabilities so that to support organizations in their attempts to make operations more effective (Morris \& Kuratko, 2002). What has been used by both domestic and international organizations in the process of competitive advantage creation is the organizational innovation creation and placing importance on launching the latest innovation to the market earlier than competitors (David, 2007; Krause, 2004) with the purpose of creating more competitive advantage for an organization on the long-term sustainable basis (Porter, 1990; Adams \& Phelps, 2006; Muammer et al., 2008). 
Integrated Strategic Management means combining methods, models and tools for diversified management so that to increase organizational working capability to achieve the required target by monitoring personnel and resources for achievement of the key performance indicator (KPI) for later achievement of a competitive advantage. An organization is required to improve the efficiency of its working processes (Shah and Ali, 2011) to cope with the external environment by changing these processes, restructuring its operations and focusing on empowering its internal management capability, efficiency of continuous process improvement as well as other proceedings related to organization's development (Robert, 1995; Holder \& Matter, 2008). As a result of continuous changes in the society, economic and political situations, any organization is required to integrate its management to support internal innovations for survival and to maintain its competitive advantage (Byrd \& Brown, 2003). Innovation does not autonomously incurs without any intention but it is the responsibility of an organization to make it happen relying on the integration of diversified concepts in order to obtain the innovation from inside the organization development.

Flexible Resource Allocation means there are enough capabilities to utilize the organization's existing resources appropriately and in accordance with the internal and external environments affecting its operations. Any organization, provided it has enough available resources accessible to use new business opportunities, would be quite able to mitigate nearly any business risk. Accessibility of resources concern first of all such spheres as budget, technology, manpower, knowledge as well as other resources contributing to effective resource management. Besides, it was stated that proper resource allocation will always encourage innovative creation behavior. Yang and Konrad (2011) in their study found that resources are the main part of an organization' s transformation capability. In case of environmental change, competitive strategy can be changed as well nd the strategy to be used will come from integration of organization' s internal resources, expertise, advantageous environment and also threats. Moreover, resources and executives' capabilities are the foundation for bringing strategy into practice (Grant, 1991).

Creativity Development is the helpful process contributing to participation in proposing ideas and new methods relevant to the working environment of an organization and applicable to all its operations. Creativity is related to mainly personnel's capability in creating new products or other extraordinary things that have never been known before. It can be developed from gathering knowledge gained from experience and then linked with new situations. As it is mentioned in (Katz, 2011), creativity is the process of a new idea development and its further presentation with the purpose of problem solving and responding to certain requirements. Success in creativity is subject to many factors such as knowledge, capabilities, technical skills, way of thinking and also environmental factors as described in (Joshi et al., 2009) who stated that creativity development not only relies on individual capabilities of certain personnel but also requires teamwork \& other activities to develop creativity and organizational context such as complicated works and monitoring support.

Also, Oldham, Greg R., Anne Cummings (1990) are of the view that creativity development is the capability of value adding to products, processes and methods encouraging personnel to present their creativity, create a good working asmosphere and open up new opportunities for everyone to participate in creative activities on the equal basis (Woodman et al, 1993). Thus, organization's achievement depends on creativity of 


\section{DEVELOPMENT OF STRATEGIC INNOVATION}

coworking among employees in various fields since each of them has their own individual set of skills, unique life experience, point of view and expertise.

\section{Conclusions}

After the review of relevant literature, concepts and fundamental theories as mentioned above, overall composition of the strategic innovation management can be concluded as follows (Figure 1).

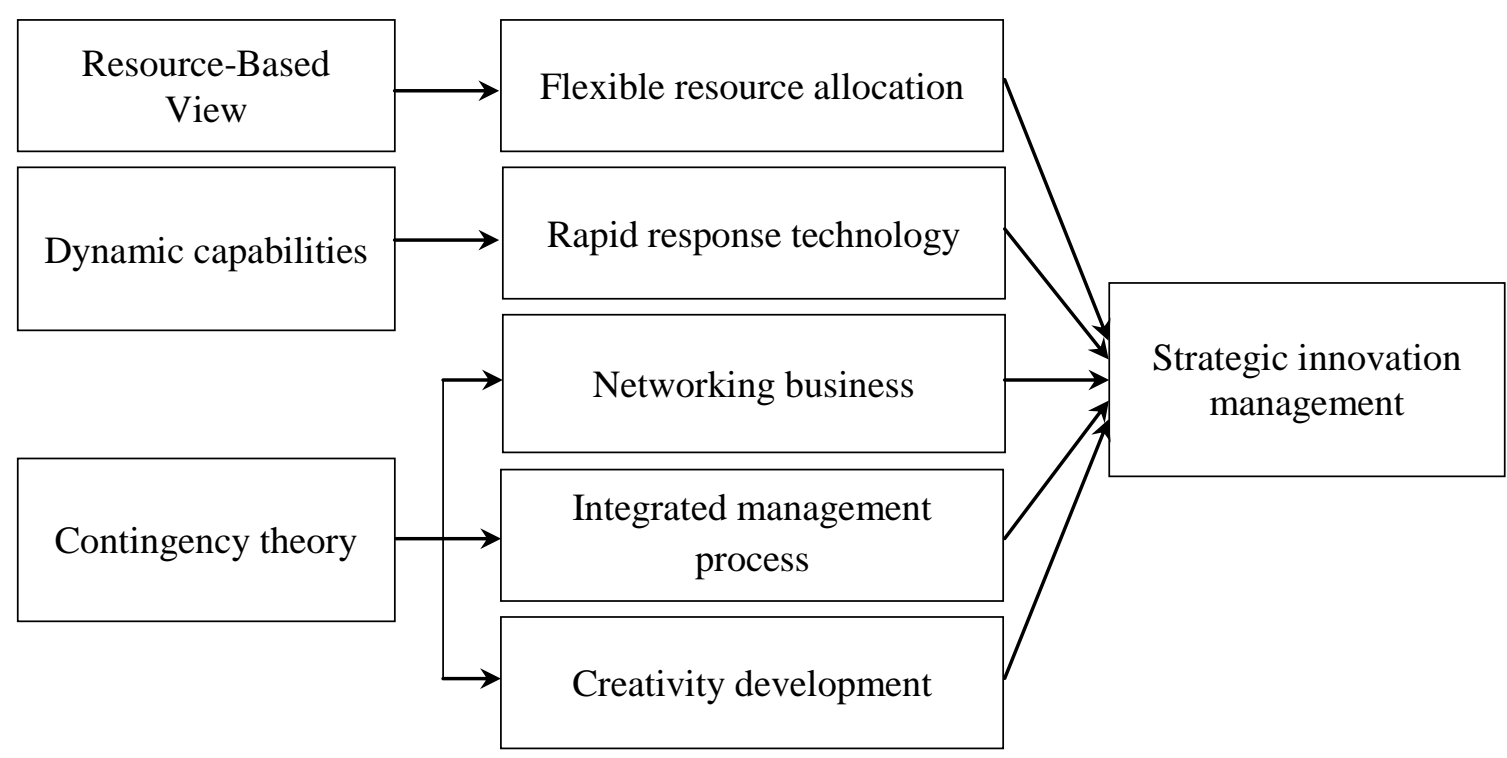

Figure 1. Composition of the strategic innovation management (constructed by the coauthors)

This figure above represents the composition of strategic innovation management formed after reviewing the related literature sources, concepts and fundamental theories. Already from this graphical presentation we can make a conclusion that strategic innovation management cannot be arisen from one factor only but via diversified factors since they enable the organization to undertake strategic innovation management. In other words, organization is required to be capable of transforming its existing resource utilization appropriately and in accordance with internal and external environment that impact its operating results. Perception and recognition as well as adjustment while catching up with technological change are essential for efficiency and flexibility of business including the development of communication, coordination among vendors, sponsors, alliances, business stakeholders and customers through sharing or networking so that to encourage better management and quality control, combining various methods, models and tools of management to increase proficiency of the working process and proposing new ideas and methods being useful for this particular organization in the achievement of its targets through personnel and resources' utilization.

This study might be found useful due to managerial aspect being directly related to awareness and recognition of strategic innovation management and relying on business 
networking, quick response to technology, management integration, flexible resource allocation and creativity development. Any organization that is able to take this into account would be also able to utilize its resources' value for future sustainable advantage and competitive capability of business.

\section{References}

Adams, R., Bessant, J., \& Phelps, R. (2006). Innovation management measurement: A review. International Journal of Management Reviews, 8(10), 21-47.

Babkin A.V., Lipatnikov V.S. \& Muraveva S. V.(2015). Assessing the impact of innovation strategies and $R \& D$ costs on the performance of IT companies. Procedia - Social and Behavioral Sciences 207.

Balslev, K. ( 2012). Product Development with Multiple Partners-Strategies and Conflicts in Networks. Industrial Marketing Management 41, 3 (April): 438-447.

Barney, J. B. \& Wright P. M. (1998). On Becomeing a Strategic Partner: The Role of Human Resources in Gaining Competitive Advantage. Human Resource Management 37: 31-46.

Barney, J. B. (1991). Firm resources and sustained competitive advantage. Journal of Management, 7(1): $99-120$.

Bean, R. \& Radford, R. (2002). The business of innovation. New York: Amacom.Goffin,

Blazevic, V., Lievens, A. \& Klein, E. (2003). Antecedents of project learning and time to market during new mobile service development. International Journal of Service Industry Management, Vol. 14 No. 1, pp. 120-147.

Byrd, J. \& Brown, P.L. (2003) The Innovation Equation: Building Creativity and Risktaking. San Francisco: Jossey-Bass/Pfeiffer.

Cooper, J. R. (1998). A multidimensional approach to the adoption of innovation. Management Decision, 36(8), 493-502

David, R. L., Ross, L. C., \& Terry, R. S. (2007). Inter-relationships between innovation and market orientation in SMEs. Management Research News, 30(12), 878.

Dess, G.G, \& Lumpkin, G.T. (2003). Strategic Management: Creating Competitive Advantages. Boston : MaGraw-Hill Irwin.

Drejer, A. (2006). Strategic innovation: a new perspective on strategic management. Handbook of Business Strategy, Vol. 7 Issue: 1, 147

Eisenhardt, K. M. \& Martin J. A. ( 2000). Dynamic Capabilities: What are They? Strategic Management Journal, 21(10-11): 1105-1121.

Glasgow, J. (2013) A critical evaluation of healthcare quality improvement and how organizational context drives performance Of a thesis submitted in partial fulfillment of the requirements for the Doctor of Philosophy degree in Epidemiology in the Graduate College of The University of Iowa

Grant, R.M. ( 1991). The Resource-Based Theory of Competitive Advantage: Implications for Strategy Formulation, California Management Review. 33(3) : 114-135.

Hinds, P. J., \& Pfeffer, J. (2002). "Why organizations don't "know what they know" - cognitive and motivational factors affecting the transfer of expertise. (V. P. V. W. E. In M. Ackerman Ed.). Cambridge MIT Press.

Hohenthal, J., Johanson, J. \& Johanson, M. (2014). Network knowledge and business-relationship value in the foreign market. International Business Review, 23, 1: 4-19.

Holder, B. J., \& Matter, G. (2008). The Innovative Organization. Accessed April 17, 2017, from http://www.geocities.com/CollegePark/Library/1048/innova.html

Homburg, C., Müller, M., \& Klarmann, M. (2011). When does salespeople's customer orientation lead to customer loyalty? The differential effects of relational and functional customer orientation. Journal of the Academy of Marketing Science, 39, 795-812. 


\section{DEVELOPMENT OF STRATEGIC INNOVATION}

Horn, C. \& Brem, A. ( 2013), Strategic directions on innovation management - a conceptual framework. Management Research Review. Vol. 36 Issue: 10, pp. 939-954.

J. Alberto Aragón-Correa and Sanjay Sharma. The Academy of Management Review. Vol. 28, No. 1 (Jan., 2003), pp. 71-88.

Jantuen, A., Ellonen, H-K. \& Johansson, A. (2012). Beyond appearances - Do dynamic capabilities of innovative firms actually differ. European Management Journal, 30: 141-155.

Jaspers, F., Hulsink, W. \& Theeuwes, J. (2007), Entry and innovation in maturing markets: virtual operators in mobile telecommunications, Jules Technology Analysis and Strategic Management, Vol. 19 No. 2, pp. 205-225.

Joshi, A., Panday, N., \& Han, G. (2009). Bracketing team boundary spanning: An examination of task-based, team-level, and contextual antecedents. Journal of Organizational Behavior, 30(6), 731-759. Retrieved from http://www.jstor.org/stable/41683864

Kijpokin Kasemsap, (2014), Strategic Innovation Management: An Integrative Framework and Causal Model of Knowledge Management, Strategic Orientation, Organizational Innovation, and Organizational Performance. Strategic Approaches for Human Capital Management and Development in a Turbulent Economy. Accessed March 6, 2017. Available from http://www.igi-global.com/chapter/strategic-innovation-management/80742

Kor, Y. Y., \& Mahoney, J. T. ( 2004). Contributions to the Resource-based View of Strategic Management. Journal of Management Studies, 41(1), 183-191.

Krause, D. E. (2004). Influence-based leadership as a determinant of the inclination to innovate and of innovation-related behaviors: An empirical investigation. Leadership Quarterly, 15(1), 79102.

Lee, Y., \& Chang, H. (2008). Relations between team work and innovation in organizations and the job satisfaction of employees: A factor analytic study. International Journal of Management, 25(4), 732-739,779. Retrieved from https://search.proquest.com/ docview/233228539? accountid=28710

Luthans, F., \& Stewart, T. I. ( 1977). A General Contingency Theory of Management. Academy Management Review, 2(2), 181-195.

Mathisen, G. \& Stale, E. ( 2004). A Review of Instruments Assessing Creative and Innovative Environments Within Organizations. Creativity Research Journal. Volume 16, 2004 - Issue 1, Pages 119-140.

McKelvie, A. \& Davidsson, P. ( 2009). From Resource Base to Dynamic Capabilities: an Investigation of New Firms. British Academy of Management, 20: 63-80.

Modell, S. (1996). A Process-Oriented Contingency Approach to Responsibility in Professional Services. International Journal of Service 8, 4 (May): 306-335.

Möller, K. \& Senja, S. (2009). How to influence the birth of new business fields-Network perspective. Industrial Marketing Management, 38, 4: 450-458.

Morris, M. H., \& Kuratko, D. F. (2002). Corporate entrepreneurship. Ohio: South-Western College Publishers.

Muammer, Z., Selcuk, B. H., \& Mete, S. (2008). Intellectual capital and innovation performance: Empirical evidence in the Turkish Automotive Supplier. Journal of Technology Management \& Innovation, 3(4), 31-40

Oke, A. (2007), Innovation types and innovation management practices in service companies. International Journal of Operations \& Production Management, Vol. 27 No. 6: 564-587.

Oldham, G. R., \& Cummings, A. (1996). Employee creativity: Personal andcontextual factors at work. Academyof Management Journal, 39, 607-634.

Orlando C. Richard. (2000), Racial Diversity, Business Strategy, and Firm Performance: A ResourceBased View. ACAD MANAGE J. April 1, 43:2 164-177.

Otley, D. (1980). The contingency theory of management accounting: achievement and prognosis", Accounting, Organizations and Society, Vol. 5 No. 4, 413-428. 
Porter, M. (1990). The competitive advantage of nations. London: Free Press.

Proctor, T. (2013). Collaboration and networking in the process of innovation: the path to precision time keeping. Journal of Management History, Vol. 19 Iss 2: 167 - 188.

Rejc, A. (2004). Toward Contingency Theory of performance measurement. Journal of East European Management Studies. Vol. 9, No. 3: 243-264.

Robbins, S.P. \& Coulter, M. (2002). Management. Upper Saddle River, NJ : Prentice-Hall, 2002.

Robert, M. (1995). Product innovation strategy pure and simple: How winning companies outpace their competitors. New York McGraw-Hill.

Schilling, M.A. (2008). Strategic Management of Technological Innovation. McGraw-Hill Education.

Shah, J. \& Ali, B. 2011. Organizational Climate: Stimulating Creativity and Idea Generation for Discovery of Innovative Solutions. Interdisciplinary Journal of Contemporary Research in Business, 3.

Smale, T. (2016). Why National Culture Should Be at the Heart of Innovation Management. Technology Innovation Management Review. Volume 6, Issue 4.

Teece, D. J. ( 2007). Explicating Dynamic Capabilities: the Nature and Micro-foundations of (sustainable) Enterprise Performance. Strategic Management Journal, 28: 1319-1350.

Teece, D. J. (2012). Dynamic Capabilities: Routines versus Entrepreneurial Action. Journal of Management Studies, 49(8): 1395-1401.

Teece, D. J., G. Pisano, \& A. Shuen (1997). Dynamic capabilities and strategic management,

Tuna, U. (2015). Innovation Culture and Strategic Human Resource Management in Public and Private Sector within the Framework of Employee Ownership. Social and Behavioral Sciences. 195. $1463-1470$.

Utterback, J. (2004). Mastering the Dynamics of Innovation. Boston: Harvard Business School Press.

Wade, M. \& Hulland, J. (2004). The Resource-Based View and Information Systems Research: Review, Extension and Suggestions for Future Research. MIS Quarterly, 28(1), 107-138.

West M.A. \& Farr J.L. (1990). Innovation at Work.In Innovation and Creativity at Work, John Wiley and Sons, Chichester.

Woodman, R. W., Sawyer, J. E. \& Griffin, R. W. (1993). Toward a Theory of Organizational Creativity. Academy of Management Review, 18(2): 293-321.

Yang, Y. and Konrad, A. M. (2011), Diversity and organizational innovation: The role of employee involvement. J. Organiz. Behav., 32: 1062-1083.

Paper submitted

Paper accepted for publishing

Paper published online
07 November 2017

09 January 2018

01 February 2018 